\title{
Hasil Diagnostik Mycobacterium Tuberculosis pada Pasien dengan Batuk $\geq 2$ Minggu Menggunakan Pewarnaan Ziehl-Neelsen Di Poliklinik Paru Rumkit Tingkat III Robert Wolter Mongisidi
}

\author{
${ }^{1}$ M. Yusril Ihza Djakaria \\ ${ }^{2}$ Fredine E. S. Rares \\ 'John Porotu'o
}

\author{
${ }^{1}$ Program Studi Pendidikan Dokter Fakultas Kedokteran Universitas Sam Ratulangi Manado \\ ${ }^{2}$ Bagian Mikrobiologi Fakultas Kedokteran Universitas Sam Ratulangi \\ Email: ihzadvbulila@gmail.com
}

\begin{abstract}
Mycobacterium tuberculosis is the causal bacteria of lung tuberculosis in human. These bacteria are classified into acid-resistant bacilli. The diagnosis of pulmonary tuberculosis can be established by microscopic examination of sputum with acid resistant bacilli dyes inter alia Ziehl-Neelsen which has high sensitivity and specificity. This was a descriptive experimental study to determine the existence of $M$. tuberculosis in the sputum of patients suffering from cough $\geq 2$ weeks at Pulmonary Polyclinic of Rumkit Tingkat III Robert Wolter Mongisidi. The results obtained 74 samples consisting of 47 males and 27 females. Based on the age group, there were 2 samples of 15-24 years; 3 samples of 25-34 years; 5 samples of 45-54 years; 5 samples of 55-64 years; 2 samples of $\geq 65$ years; none of 35-44 years old. There were 17 TB positive samples and 57 TB negative samples. Most of the TB positive samples were females (11 of 17 samples) and of age group 45-54 years as well as of 55-64 years. Conclusion: Most of the TB positive patients were female, and aged 45-64 years old.
\end{abstract}

Keywords: Cough of more than 2 weeks, Mycobacterium tuberculosis, lung tuberculosis

\begin{abstract}
Abstrak: Mycobacterium tuberculosis merupakan bakteri agen penyebab penyakit tuberkulosis (TB) pada manusia yang sering menginfeksi paru-paru. Bakteri ini digolongkan ke dalam basil tahan asam (BTA). Untuk menegakkan diagnosis TB dapat dilakukan dengan fasilitas sederhana dan memberi sensitivitas serta spesifisitas yang cukup tinggi yaitu pemeriksaan sputum dengan pewarnaan Ziehl-Neelsen. Jenis penelitian ini ialah deskriptif eksperimental untuk menentukan ada tidaknya Mycobacterium tuberculosis pada sputum pasien batuk $\geq 2$ minggu di Poliklinik Paru Rumkit Tingkat III Robert Wolter Mongisidi. Pengambilan sampel dilakukan pada bulan Oktober-November 2017. Hasil penelitian mendapatkan 74 sampel terdiri dari 47 laki-laki dan 27 perempuan. Berdasarkan kelompok usia didapatkan 2 sampel usia 15-24 tahun; 3 sampel usia 25-34 tahun; 5 sampel usia 45-54 tahun; 5 sampel usia 55-64 tahun; dan 2 sampel usia $\geq 65$ tahun. Tidak ada sampel pada usia 35-44 tahun. Pada pemeriksaan sputum ditemukan BTA positif pada 17 sampel dan BTA negatif pada 57 sampel. Pemeriksaan sputum dengan BTA positif terbanyak didapatkan pada jenis kelamin perempuan (11 dari 17 sampel), serta kelompok usia 45-54 tahun dan 55-64 tahun. Simpulan: Sebagian besar pengidap tuberkulosis berjenis kelamin perempuan dan berusia 45-64 tahun.
\end{abstract}

Kata kunci: batuk $\geq 2$ minggu, Mycobacterium tuberculosis, TB paru

Mycobacterium tuberculosis merupakan bakteri agen penyebab penyakit tuberku- losis (TB) pada manusia yang sering menginfeksi paru-paru. ${ }^{1} \quad$ Bakteri ini 
digolongkan ke dalam bakteri tahan asam (BTA) dan bersifat batang Gram positif. ${ }^{2}$ M. tuberculosis ditularkan pengidap yang terinfeksi melalui udara (percikan ludah) dengan cara batuk, bersin, atau berbicara. Ruangan yang memiliki ventilasi buruk dapat menjadi faktor risiko yang tinggi dalam penularan bakteri ini. ${ }^{1}$

Gejala klinis yang klasik dari TB paru antara lain batuk kronis. Batuk merupakan gejala respiratorik dari TB paru yang pada awalnya terjadi karena iritasi pada bronkus. Batuk juga diperlukan untuk mengeluarkan sputum dari saluran pernapasan yang diproduksi karena terjadinya radang., Penderita TB paru dapat disertai batuk darah akibat dari pecahnya pembuluh darah yang berasal dari kavitas atau pecahnya pembuluh darah pada bronkus. ${ }^{5}$

Selain berpatokan pada gejala klinis, diagnosis TB paru dengan pemeriksaan mikroskopik sputum (pemeriksaan BTA) sangat mendukung sarana-sarana diagnostik lainnya. Pemeriksaan sputum penting untuk mendeteksi kuman M. tuberculosis, dan dengan ditemukannya kuman ini pada sputum maka dapat ditegakkan diagnosis TB paru. Pemeriksaan mikroskopik dengan metode pewarnaan Ziehl-Neelsen mudah dilakukan, tidak memerlukan biaya tinggi, dapat dilakukan dengan fasilitas sederhana dan memberi sensitivitas dan spesifisitas yang cukup tinggi. ${ }^{5,6}$

Tuberkulosis hingga hari ini masih merupakan masalah besar di Indonesia. ${ }^{2}$ Data WHO menunjukkan Indonesia termasuk dalam 30 negara dengan beban TB yang besar dengan angka mencapai 395 per 100.000 penduduk. ${ }^{7}$ Hasil Riset Kesehatan Dasar (Riskesdas) tahun 2013 mendapatkan prevalensi penduduk Indonesia yang didiagnosis menderita TB paru oleh tenaga kesehatan adalah $0,4 \%$. Provinsi Sulawesi Utara berada pada angka $0,3 \%$ dan prevalensi ditemukannya gejala batuk $\geq 2$ minggu sebesar $4,1 \% .^{8}$ Data Dinas Kesehatan Provinsi Sulawesi Utara tahun 2014 menyebutkan bahwa jumlah kasus baru TB dengan BTA positif sebesar 3.233 kasus untuk laki-laki dan 1.993 kasus untuk perempuan. ${ }^{9}$
Hasil observasi di Poliklinik Paru Rumkit Tingkat III Robert Wolter Mongisidi ditemukan pasien berobat dengan keluhan batuk $\geq 2$ minggu selama bulan Januari 2017 sebanyak 43 pasien. Penelitian ini bertujuan untuk untuk menentukan ada tidaknya $M$. tuberculosis pada sputum penderita batuk $\geq 2$ minggu di Poliklinik Paru Rumkit Tingkat III Robert Wolter Mongisidi.

\section{METODE PENELITIAN}

Jenis penelitian ini ialah deskriptif eksperimental. Subyek penelitian ialah pasien dengan batuk $\geq 2$ minggu di Poliklinik Paru Rumkit Tingkat III Robert Wolter Mongisidi. Pengambilan sampel menggunakan total sampling pada kurun waktu Oktober-November 2017.

Pengambilan sputum sesuai dengan pemeriksaan dahak sewaktu-pagi-sewaktu kemudian sampel sputum yang diperoleh diproses dengan pewarnaan Ziehl-Neelsen dan diperiksa menggunakan mikroskop pembesaran 1000x.

\section{HASIL PENELITIAN}

Pada penelitian yang dilakukan di Rumkit Tingkat III Robert Wolter Mongisidi periode Oktober-November 2017 didapatkan 74 pasien dengan batuk $\geq 2$ minggu. Tabel 1 menunjukkan bahwa pasien batuk $\geq 2$ minggu lebih banyak berjenis kelamin laki-laki $(63,51 \%)$ dibandingkan perempuan $(36,49 \%)$.

Tabel 1. Distribusi pasien berdasarkan jenis kelamin

\begin{tabular}{ccc}
\hline Jenis kelamin & Jumlah & \% \\
\hline Laki-laki & 47 & 63,51 \\
Perempuan & 27 & 36,49 \\
Total & 74 & 100,00 \\
\hline
\end{tabular}

Pada Tabel 2 pasien batuk $\geq 2$ minggu paling banyak ditemukan pada kelompok usia $\geq 65$ tahun $(35,13 \%)$, kemudian kelompok usia 55-64 tahun $(24,32 \%)$, 4554 tahun $(17,57 \%), 15-24$ tahun $(9,46 \%)$; kelompok usia 25-34 tahun dan 35-44 tahun memiliki persentase sama $(6,76 \%)$. 
Tabel 2. Distribusi pasien berdasarkan kelompok usia

\begin{tabular}{ccc}
\hline Kelompok usia & Jumlah & \% \\
\hline 15-24 tahun & 7 & 9,46 \\
25-34 tahun & 5 & 6,76 \\
35-44 tahun & 5 & 6,76 \\
45-54 tahun & 13 & 17,57 \\
55-64 tahun & 18 & 24,32 \\
$\geq 65$ tahun & 26 & 35,13 \\
Total & 74 & 100,00 \\
\hline
\end{tabular}

Tabel 3 menunjukkan jumlah pasien dengan hasil BTA positif sebanyak 22,97\% dan penderita dengan hasil BTA negatif sebanyak $77,03 \%$.

Tabel 3. Distribusi pasien berdasarkan hasil pewarnaan Ziehl-Neelsen

\begin{tabular}{lcc}
\hline Hasil & Jumlah & \% \\
\hline BTA (+) & 17 & 22,97 \\
BTA (-) & 57 & 77,03 \\
Total & 74 & 100,00 \\
\hline
\end{tabular}

Tabel 4 menampilkan jumlah pasien batuk $\geq 2$ minggu dengan hasil pewarnaan Ziehl-Neelsen BTA positif $(+)$ berjenis kelamin laki-laki sebanyak 6 orang $(35,29 \%)$ dan berjenis kelamin perempuan sebanyak 11 orang $(64,71 \%)$.

Tabel 4. Distribusi pasien dengan hasil BTA positif berdasarkan jenis kelamin

\begin{tabular}{ccc}
\hline Jenis kelamin & Jumlah & \% \\
\hline Laki-laki & 6 & 35,29 \\
Perempuan & 11 & 64,71 \\
Total & 17 & 100,00 \\
\hline
\end{tabular}

Tabel 5 menunjukkan jumlah pasien batuk $\geq 2$ minggu yang memiliki hasil pewarnaan Ziehl-Neelsen BTA positif $(+)$ dengan kelompok usia 15-24 tahun sebanyak 2 orang (11,7\%), 25-34 tahun sebanyak 3 orang $(17,64 \%), 35-44$ tahun tidak ada, 45-54 tahun sebanyak 5 orang $(29,41 \%), 55-64$ tahun sebanyak 5 orang $(29,41 \%)$, dan $\geq 65$ tahun sebanyak 2 orang $(11,77 \%)$.
Tabel 5. Distribusi pasien dengan hasil BTA positif berdasarkan kelompok umur

\begin{tabular}{ccc}
\hline Kelompok usia & Jumlah & \% \\
\hline 15-24 tahun & 2 & 11,77 \\
25-34 tahun & 3 & 17,64 \\
35-44 tahun & 0 & 0 \\
45-54 tahun & 5 & 29,41 \\
55-64 tahun & 5 & 29,41 \\
$\geq 65$ tahun & 2 & 11,77 \\
Total & 17 & 100,00 \\
\hline
\end{tabular}

\section{BAHASAN}

Penelitian ini dilakukan pada pasien batuk $\geq 2$ minggu di Rumkit Tingkat III Robert Wolter Mongisidi. Pemeriksaan yang dilakukan ialah pemeriksaan ZiehlNeelsen di Laboratorium Mikrobiologi Fakultas Kedokteran Universitas Sam Ratulangi dan Laboratorium Rumkit Tingkat III Robert Wolter Mongisidi.

Distribusi sampel 74 pasien batuk $\geq 2$ minggu berdasarkan jenis kelamin yaitu laki-laki sebanyak 47 orang $(63,51 \%)$ dan perempuan sebanyak 27 orang $(36,49 \%)$. Pada penelitian ini didapatkan dari 47 orang laki-laki pasien batuk $\geq 2$ minggu hanya 6 orang yang mendapatkan hasil pewarnaan BTA positif sedangkan perempuan dari 27 pasien didapatkan hasil BTA positif sebanyak 11 orang (Tabel 4). Hal ini berbeda dengan penelitian sebelumnya yang menyatakan bahwa laki-laki memiliki risiko lebih besar untuk mengidap penyakit TB paru dibandingkan perempuan. ${ }^{10}$

Jumlah pasien TB paru pada laki-laki hampir dua kali lipat dibadingkan jumlah pasien TB paru pada perempuan. Tuberkulosis paru lebih banyak terjadi pada lakilaki dibandingkan pada perempuan karena sebagian besar laki-laki mempunyai kebiasaan merokok sehingga memudahkan terjangkitnya tuberkulosis paru. ${ }^{11}$ Nikotin yang terkandung dalam rokok menghambat produksi tumour necrosis factor-alpha (TNF- $\alpha$ ) di makrofag pada paru-paru, sehingga menyebabkan perokok lebih rentan terinfeksi $M$. tuberculosis. ${ }^{12}$

Menurut WHO, secara global laki-laki lebih berisiko untuk mengidap penyakit TB 
dibandingkan perempuan. Pada tahun 2015 enam juta laki-laki dewasa mengidap tuberculosis, dibandingkan dengan perempuan yang mengidap mencapai 3,5 juta. ${ }^{13}$ Tuberkulosis termasuk lima penyakit yang paling mematikan untuk perempuan dengan usia 20-59 tahun. ${ }^{14}$

Tingginya angka TB paru pada lakilaki ini disebabkan oleh beberapa faktor, di antaranya faktor sosioekonomi dan budaya yang menyebabkan terbatasnya akses perempuan ke fasilitas kesehatan sehingga kurangnya laporan penyakit tuberkulosis utamanya pada negara-negara berkembang. Selain itu, faktor biologi yaitu hormon yang berkaitan dengan jenis kelamin juga memengaruhi angka kejadian penyakit TB pada laki-laki dan perempuan. Hormon yang berkaitan dengan jenis kelamin ialah hormon estrogen, hormon ini meningkat pada perempuan usia produktif dan berfungsi meningkatkan aktivasi makrofag dan iNKT sehingga meningkatkan imunitas melawan infeksi bakteri. ${ }^{15}$ Hal ini yang merupakan penyebab lebih besarnya jumlah pengidap perempuan dengan BTA positif, karena dilihat dari sisi usia sudah melampaui usia produktif.

Distribusi 74 sampel pasien batuk $\geq 2$ minggu berdasarkan usia di Rumkit Tingkat III Robert Wolter Mongisidi yaitu terbanyak pada usia $\geq 65$ tahun $(35,13 \%)$, disusul oleh usia 45-54 tahun ((17,57\%), dan 55-64 tahun $(24,32 \%)$. Jumlah pasien batuk $\geq 2$ minggu yang memiliki hasil pewarnaan Ziehl-Neelsen BTA positif (+) dengan kelompok usia terbanyak ialah 4554 tahun dan 55-64 tahun (masing-masing sebesar 29,41\%), disusul oleh 25-34 tahun sebanyak 3 orang $(17,64 \%)$,

Usia berperan dalam kejadian penyakit tuberkulosis. Risiko untuk mendapatkan penyakit TB digambarkan seperti kurva normal yang terbalik. Tinggi saat awal kemudian mulai berkurang ketika memasuki usia 2 tahun hingga dewasa karena memiliki imunitas yang baik terhadap $M$. tuberculosis. Dasarnya saat dewasa muda dan naik lagi menjelang dewasa tua, namun, di Indonesia diperkirakan sekitar
$75 \%$ dari pengidap TB berada pada usia produktif yaitu15-50 tahun. ${ }^{11}$

Distribusi 74 sampel pasien batuk $\geq 2$ minggu berdasarkan hasil pemeriksaan pewarnaan Ziehl-Neelsen di Rumkit Tingkat III Robert Wolter Mongisidi yaitu yang memiliki hasil pewarnaan BTA positif (+) sebanyak 17 orang $(22,97 \%)$ dan yang memiliki hasil pewarnaan BTA negatif (-) sebanyak 57 orang $(77,03 \%)$. Hasil ini berbeda dengan penelitian yang dilakukan oleh Wijaya di Manado pada tahun 2011 yang menyatakan bahwa dari total pasien yang diduga menderita TB, terdapat sebanyak 670 sampel dengan hasil BTA positif dan 220 sampel dengan hasil BTA negatif. $^{16}$

\section{SIMPULAN}

Dari hasil penelitian ini dapat disimpulkan bahwa jenis kelamin laki-laki dan kelompok usia $\geq 65$ tahun yang terbanyak menderita batuk $\geq 2$ minggu.

Dari hasil sampel sputum yang positif BTA didapatkan yang terbanyak ialah jenis kelamin perempuan dengan rentang usia 45-64 tahun.

\section{SARAN}

Diperlukan peningkatan pengendalian tuberkulosis paru pada masyarakat.

Disarankan untuk melakukan penelitian lanjut di rumah sakit lain di Kota Manado untuk mendapatkan gambatan menyeluruh dari rumah sakit di Kota Manado.

\section{DAFTAR PUSTAKA}

1. Longo DL, Kasper DL, Jameson JL, et al, editors. Harrison's Principles of Internal Medicine $\left(18^{\text {th }}\right.$ ed). USA: McGraw-Hill, 2012.

2. Buntuan V. Gambaran basil tahan asam (BTA) positif pada penderita diagnosa klinis tuberkulosis paru di Rumah Sakit Islam Sitti Maryam Manado periode Januari 2014 s/d Juni 2014. eBM. 2014;2:593-96.

3. Zumla A, Raviglione M, Hafner R, Reyn CFR. Current concepts tuberculosis. NEJM. 2013;21;368(8):745-55. 
4. Perhimpunan Dokter Paru Indonesia. Tuberkulosis: Pedoman diagnosis dan penatalaksanaan. 2006. Available from: http://www.klikpdpi.com/

konsensus/tb/tb.html.

5. Sudoyo AW, Setiyohadi B, Alwi I, K Simadibrata M, Setiati S, editors. Buku Ajar Ilmu Penyakit Dalam Jilid 2 (4th ed). Jakarta: Pusat Penerbitan Departemen Ilmu Penyakit Dalam Fakultas Kedokteran Universitas Indonesia, 2006.

6. Karuniawati A, Risdiyani E, Nilawati S, Prawoto, Rosana Y, Alisyahbana B, et al. Perbandingan Tan Thiam Hok, Ziehl Neelsen, dan fluorokrom sebagai metode pewarnaan basil tahan asam untuk pemeriksaan mikroskopik sputum. Makara Kesehatan. 2005;9(1):29-33.

7. World Health Organization. Global tuberculosis report 2016. Geneva: WHO Press, 2016.

8. Riset kesehatan dasar: riskesdas 2013. Badan Penelitian dan Pengembangan Kesehatan Kementerian Kesehatan RI. Jakarta: Kemenkes RI. 2013.

9. Dinas Kesehatan Provinsi Sulawesi Utara. Profil kesehatan Provinsi Sulawesi Utara 2014. Manado: Dinas Kesehatan Provinsi
Sulawesi Utara, 2015.

10. United Nations Development Programme. Discussion Paper; Gender and tuberculosis, 2015.

11. Fitriani, E. Faktor risiko yang berhubungan dengan kejadian tuberkulosis paru. UJPH. 201;2(1):1-7.

12. Kolappan C, Gopi PG, Subramani, Narayanan PR. Selected biological and behavioural risk factors associated with pulmonary tuberculosis. Intt $\mathbf{J}$ Tuberc Lung Dis. 2007;11(9):999-1003.

13. World Health Organization. Tuberculosis and gender. [cited 2017 Dec 10]. Available from: http://www.who.int/tb/areas-ofwork/population-groups/gender/en/.

14. World Health Organization. Tuberculosis in women, 2016.

15. Neyrolles O, Quintana-Murci L. Sexual inequality in tuberculosis. PLoS Medicine. 2009;6(12):1-6.

16. Susanti D, Kountul C, Buntuan V. Pemeriksaan basil tahan asam (BTA) pada sputum penderita batuk $\geq 2$ minggu di Poliklinik Penyakit Dalam RSUP Prof. Dr. R.D. Kandou Manado. eCl. 2013;1(1). 